\title{
The Effect of Storytelling Marketing on Purchasing Decisions Through Brand Equity as Intervening Variable on Gojek in Jakarta
}

\author{
Ridha Rizkia*, Farah Oktafani \\ Business Administration, Telkom University, Indonesia
}

\begin{abstract}
As the capital city, Jakarta has become a city of traffic jams due to its dense and productive population. A private motorbike or motorcycle taxi is a choice to deal with traffic jams. Gojek appears and becomes a solution for complaints against conventional motorcycle taxis. Many companies, including Gojek, are competing to do promotions to attract the attention of consumers. Gojek uses storytelling marketing strategies in creating advertisements and content in their social media. This research was conducted to determine the effect of storytelling marketing $(\mathrm{X})$ on purchasing decisions (Y) through brand equity (Z) as an intervening variable. The analysis technique in this study uses quantitative methods with the type of exploratory research. Non-probability used as a sampling method with the type of purposive sampling. The population size in this study was unknown and the sample used was 100 respondents. Based on a descriptive analysis of storytelling marketing variables $(\mathrm{X})$, brand equity $(\mathrm{Z})$ and purchasing decisions $(\mathrm{Y})$ are in a good category. While the results of the PLS analysis found that storytelling marketing influences purchasing decisions through brand equity as an intervening variable.
\end{abstract}

Keywords: Brand Equity, Purchasing Decision, Storytelling Marketing

This is an open access article under the CC-BY-NC license.

\section{INTRODUCTION}

According to data from TomTom, one of the technology companies which regulates traffic, Jakarta is on the 7th place of "extra travel time" city with a percentage of 53\% (www.cnbcindonesia.com). A choice for citizens to break through the traffic jam, besides riding a private motorbike is using a taxi bike. Unfortunately, there are various complaints about conventional taxi bike. Along with the growth of technology, Gojek appears as a taxi bike solution which was a public complaint. Along with marketing science development, nowadays, consumers also involve their experience and emotions while using a product or service. One method that can touch a consumer's emotions while using a brand's product or service is experimental marketing. Storytelling marketing trends emerge as experimental marketing develops. Storytelling marketing has become one of growing and developing marketing strategies, because storytelling has a strength that has been recognized widely in all disciplines, including marketing (Lowe in Pan, Lee-Yun. Kuan-Hung Chen, 2019). Storytelling requires planning that consists of an audience as a brand target, message to be delivered, casts, scenarios to be run, and the costs to conduct the storytelling marketing. Elements to make a storytelling marketing according to Kakroo in Pan, LeeYun. Kuan-Hung Chen (2019), is the plot, characters, and aesthetics. Gojek used the storytelling marketing strategy either to create advertisements or social media content. A storytelling marketing strategy can create brand equity because it will ease consumers to remember a brand. Furthermore, according to the result of research by Hanggadika (2010), the higher the brand equity of a brand the higher the consumer purchasing decision is because the elements of brand equity influencing purchasing decisions significantly.

*Corresponding author ridharizkia98@gmail.com*; farahokt@gmail.com DOI: https://doi.org/10.31098/ijmesh.v3i1.190 
Based on the description above, Gojek sees the opportunity from storytelling marketing to create brand equity. Brand equity becomes the intervening variable on storytelling marketing influence on purchasing decisions.

\section{LITERATURE REVIEW}

Storytelling Marketing

Storytelling marketing is a description where the company combines the company's identity with the company's philosophy to create product or service activity (Salzer-Morling \& Stannegard, 2004:224). While according to Bryan (2011:13), the story is a narrative of various events created with a strategy for attracting the public. Stephen Denning (2004:5), argues that storytelling is an effective way to be implemented, but it should choose the right story, make the right adjustment and it should match the situation. Several objects obtained by storytelling marketing are triggering acts, communicating a brand, transmitting values, triggering collaboration, resolving rumors, sharing knowledge, and leading people to the future.

\section{Brand Equity}

Brand equity is an asset and trust about a certain brand so that it can influence the value given by the product or service (Kotler and Keller, 2009). According to Aaker in Tjiptono (2011:97) on creating brand equity, there are five important aspects, those are brand awareness, brand quality, brand association, perceived quality, and brand loyalty.

\section{Purchasing Decision}

Purchasing decision according to Kotler and Keller (2012:167) is deciding to continue or no longer carry out the purchasing activities. While Peter and Olson (2013:163) argue that purchasing decision is making an alternative decision about choices that will be taken, product and service that will be purchased, purchasing period, purchasing a place, and ways to purchase. In understanding purchasing decisions there are several elements, there are product choices, brand choices, supplier choices, purchase time, the purchase amount, and payment method (Kotler and Keller, 2016:187).

\section{METHODOLOGY}

Types of research used were descriptive and causal research. This research will find out the relation between storytelling marketing to purchasing decisions through brand equity as an intervening variable. Likert scale was used as the instrument scaling in this research. Gojek consumer in Jakarta is a population in this study and because it has the unknown size, thus it was used Bernoulli formula. Based on that formula, the result of the sampling size in this study is 100 respondents. This study used a $5 \%$ alpha level of accuracy and a 95\% confidence level, so a $Z$ value was 1,96. The sampling method used was nonprobability sampling. Respondents in this research were Gojek customers in Jakarta who have watched or read the content of storytelling marketing from Gojek.

This study used Descriptive Analysis and Partial Least Square Analysis. The validity test parameter used is if the loading factor value, average variance extracted (AVE), and community has a higher value than 0,5 , square root of AVE is higher than the correlation of latent variable and the crossloading value is higher than 0,5 . The reliability test in PLS is Cronbach's alpha and composite reliability. Hypothesis testing is known from the value of T-statistic and probability with statistic value that was used then for alpha $5 \%$ the T-statistic value used was 1,98. Thus, the acceptance or rejection criteria for 
International Journal of Management, Entrepreneurship, Social Science and Humanities (IJMESH), Vol. 3 (1), 48-55

The Effect of Storytelling Marketing on Purchasing Decisions Through Brand Equity as Intervening Variable on Gojek in Jakarta

Ridha Rizkia, Farah Oktafani

hypothesis are Ha accepted Ho rejected if T-statistic > 1,98. In rejecting or accepting a hypothesis with probability, Ha will be accepted if the p-value $<0,05$.

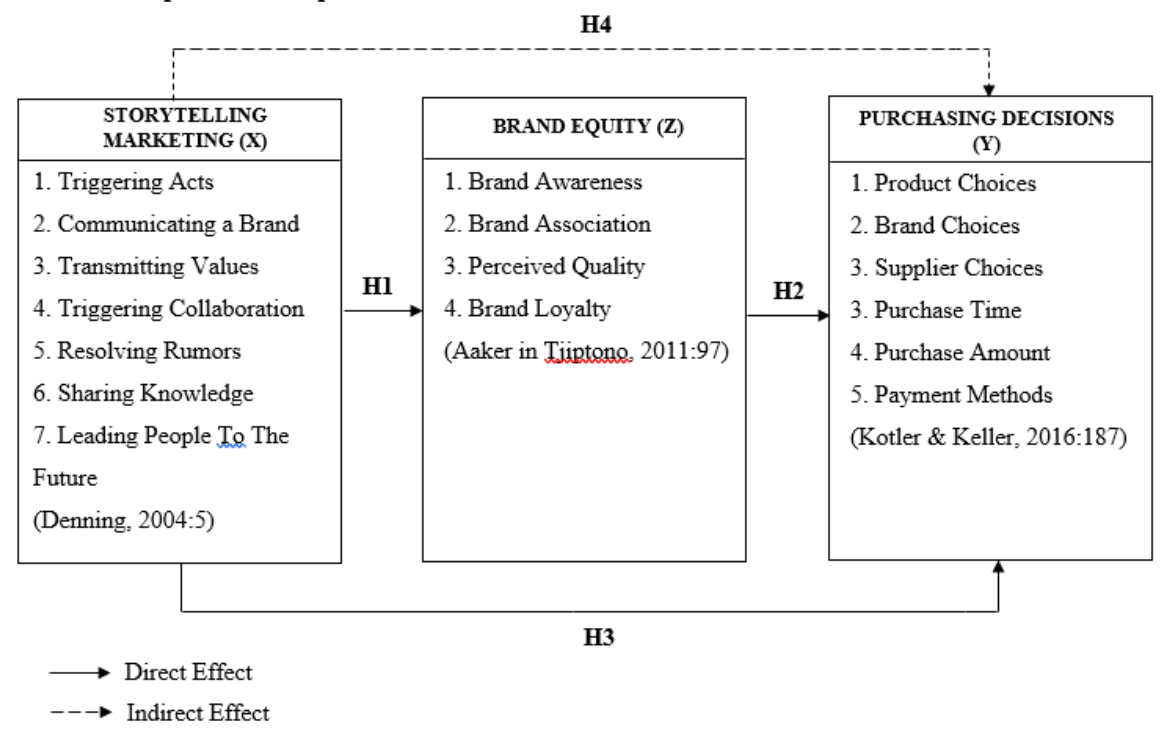

Fig. 1 Research Framework

\section{RESULTS AND DISCUSSION}

Storytelling Marketing

From the descriptive analysis that has been done regarding the respondent's responses to the Gojek storytelling marketing, the overall percentage is $69,9 \%$ (good category). It means Gojek storytelling marketing can deliver Gojek's values and give an image of Gojek well. They are realized that Gojek has storytelling content that will deliver positive messages for customers. It can be seen from the highest score in the descriptive analysis of storytelling marketing which stated "the story motivated me to be a better person" with a total score of 389 and a percentage of $77,8 \%$. This statement with the highest score is a value transmission indicator. According to Stephen Denning (2004:5), the effective way to embed brand values to the audience is through storytelling. This thing proves that contact from Gojek storytelling marketing has succeeded in delivering the values that Gojek holds also touches the customer's emotions. So, the customers are motivated and want to apply those values to their own life.

And then, the statement with the lowest value is "I want to drop comments in comments column after watching or reading that story" with 292 for score and 58,4\% for the percentage. This statement with the lowest score is an indicator of collaboration triggers dimension. According to Stephen Denning (2004:5), the audience must feel that their emotion is touched, so the audience wants to comment also share the experience. It is a prove that Gojek storytelling marketing content has less power to make customer participating with commenting. Besides that, the storytelling marketing variable has adequate the validity and reliability test as a requirement to conduct the hypothesis test and in a valid number (higher than 0,5), also has a reliable number (higher than 0,07 amounted to 0,916 ).

Brand Equity 
From the descriptive analysis that has been done regarding the respondent's responses to the brand equity of Gojek, the overall percentage is $69,84 \%$ (good category). It means that brand equity of Gojek is strong and attached enough to the customer's mind. They are realized that Gojek has something different among other competitors. As can be seen from the highest score from the descriptive analysis of brand equity with the statement of "I think Gojek has the uniqueness than another competitor", with 362 as the score with a percentage of $72,4 \%$. This statement with the highest score is an indicator of brand association. According to Aaker (2004:407), the brand association is the whole aspects that stick in the customer's mind about that brand. This proved that Gojek has its specialty that more attached to customer's minds than the competitors.

Then, the statement with the low score is "I prefer using Gojek to competitors" with a total 325 and a percentage of $65 \%$. This lowest score statement is an indicator of the brand loyalty dimension. Proved that pretty much customers who prefer to used services from competitors and the low level of brand loyalty from Gojek customer. Besides that, the brand equity variable has adequate to validity and reliability test as a requirement for hypothesis test and the result is valid (higher than 0,5 ) and reliability value higher than 0,07 (amount of reliability value is 0,858 ).

Purchasing Decision

From the descriptive analysis that has been done regarding the respondent's responses to the purchasing decision of Gojek, the overall percentage is 72,8\% (good category). It means that Gojek has succeeded in influencing customers in making purchasing decisions through Gojek's excellences. As it can be seen from the highest score from the descriptive analysis of purchasing decision with the statement of "Gojek's features are easy to use", with 403 as the score with the percentage of 80,6\%. This statement with the highest score is an indicator of supplier choice. According to Kotler \& Keller (2016:187), customers need to choose the supplier to get the product or services they needed. Several factors that customers consider to choose the right supplier, one of them is Gojek's features. It proves that Gojek's features are really user friendly.

And then the statement with the low score is "It's faster to get a driver with Gojek than competitors" with a total 334 and a percentage of $66,8 \%$. It proves that many customers get drivers faster when using a competitor's service than Gojek. Besides that, the purchasing decision variable has adequate to validity and reliability test as a requirement for hypothesis test and the result is valid (higher than 0,5 ) and reliability value higher than 0,07 (amount of reliability value is 0,901 ).

The influence of storytelling marketing to brand equity on Gojek in Jakarta

Based on the hypothesis test conducted, the researcher was using SmartPLS, obtained a T-statistic value of 7,887, and the level of significance $>1,98$. Because this hypothesis test has fulfilled the requirement that $\mathrm{t}$-count is higher than $\mathrm{t}$-table 1,98 , so it can be concluded that storytelling marketing affecting brand equity. R square explained that affect the score of storytelling marketing to brand equity has the R square value of 0,313 or $31,3 \%$ and other $67,8 \%$ explained by the variable that not used in this study. This research supported by the result of Meika Alicia's thesis entitled "Performance Analysis of Storytelling Marketing on Brand Equity in Carbonated Drink Product Coca Cola" which stated that storytelling marketing has a positive effect on brand equity, the higher storytelling performance of Gojek the higher brand equity of Gojek. Other research that supported this research is a statement from Kotler (2000) who stated that there is a certain impression on a brand after the brand is seen, read, felt by product brand in various media, such as TV, radio, or printed media. The result of this research is also 
International Journal of Management, Entrepreneurship, Social Science and Humanities (IJMESH), Vol. 3 (1), 48-55

The Effect of Storytelling Marketing on Purchasing Decisions Through Brand Equity as Intervening Variable on

Gojek in Jakarta

Ridha Rizkia, Farah Oktafani

supported by the journal from Nirakatriena et al. (2018) which stated that storytelling marketing influences brand equity significantly. Storytelling marketing has an important role to Gojek marketing. With an attractive storytelling marketing strategy, the customer will be easier to keep Gojek in their minds and improving Gojek's brand equity. So, the storytelling marketing test affected to brand equity, the result is Ho rejected. The hypothesis of storytelling marketing affected brand equity is accepted.

The influence of brand equity in purchasing decision on Gojek in Jakarta

Based on the hypothesis test conducted, the researcher was using SmartPLS, obtained a T-statistic value of 10,904, and the level of significance $>1,98$. Because this hypothesis test has fulfilled the requirement that $\mathrm{t}$-count is higher than $\mathrm{t}$-table 1,98 , so it can be concluded that brand equity affecting purchasing decisions. This research is supported by the result of research by Komang Suharyani (2015) which stated that brand equity affected positively to purchasing decisions. This research also supported by research from Durianto et al (2014) that stated, to able to differentiate other products on purchasing decisions, it needs a brand equity role. It means, the higher brand equity, the purchasing decision will better. So, the test of brand equity influencing purchasing decisions has a result that Ho is rejected. The hypothesis of brand equity affected purchasing decision is accepted.

The influence of storytelling markering to purchasing decision on Gojek in Jakarta

Based on the hypothesis test conducted, the researcher was using SmartPLS, obtained a T-statistic value of 7,887, and the level of significance $>1,98$. Because this hypothesis test has fulfilled the requirement that $\mathrm{t}$-count is higher than $\mathrm{t}$-table 1,98 , so it can be concluded that storytelling marketing affecting purchasing decisions. $\mathrm{R}$ square explained that affect the score of storytelling marketing to purchasing decision has the $\mathrm{R}$ square value of 0,646 or $64,6 \%$ and other $35,4 \%$ explained by the variable that not used in this study. This research is supported by the result of Meika (2014) that stated storytelling marketing affected positively to purchasing decisions. This research is also in line with the theory from Frog, Budtz, Munch \& Blanchette (2010) that stated long-term platforms can be formed by storytelling to reach the object that is main selling, enlarging knowledge, and strengthening brand image, also create consumer behavior that affected to purchasing decision. It means, better storytelling marketing of Gojek will make a better purchasing decision. So, the test of storytelling marketing influencing purchasing decisions has a result that Ho is rejected. The hypothesis of storytelling marketing affected purchasing decision is accepted.

The influence of storytelling markering to purchasing decision through brand equity on Gojek in Jakarta

Based on the hypothesis test conducted, the researcher was using SmartPLS, obtained a Tstatistic value of 7,225 with total indirect effect, and the level of significance $>1,98$. Because this hypothesis test has fulfilled the requirement that t-count is higher than t-table 1,98, so it can be concluded that storytelling marketing affected purchasing decisions through brand equity as an intervening variable. This research is supported by Nirakatriena dkk (2018) which stated that brand equity has a role as an intervening variable so it will strengthen the storytelling marketing variable to purchasing decision variables. It means that the better Gojek's brand equity, the better storytelling marketing to purchasing decisions. So, the test of storytelling marketing influencing purchasing decisions through brand equity as an intervening variable has the result that Ho is rejected. The hypothesis of storytelling marketing influencing purchasing decisions through brand equity is accepted.

\section{CONCLUSION}


The purpose of this research is to determine the effect of storytelling marketing on purchasing decisions through brand equity as an intervening variable on Gojek in Jakarta. The population in this research is unknown and the sample used was 100 respondents. Respondents of this research were Gojek customers who have watched or read storytelling marketing content from Gojek. Based on research about storytelling marketing influencing purchasing decision through brand equity, it can be concluded that:

Storytelling marketing overview on Gojek in Jakarta

From the descriptive analysis conducted about the response by respondents on the storytelling marketing variable on Gojek, the result of the overall percentage is 69,9\% (in good category). It means that storytelling marketing on Gojek can deliver the message that Gojek hold and give the overview of Gojek to the customer in Jakarta well. It can be seen from the highest score in the descriptive analysis of storytelling marketing which stated "the story motivated me to be a better person" with a total score of 389 and a percentage of $77,8 \%$.

Brand Equity overview on Gojek in Jakarta

From the descriptive analysis conducted about the response by respondents on the brand equity variable on Gojek, the result of the overall percentage is $69,84 \%$ (in good category). It means that Gojek is sticking enough in the customer's mind. They are realized that Gojek has something different over the competitor. As can be seen from the highest score from the descriptive analysis of brand equity with the statement of "I think Gojek has the uniqueness than another competitor", with 362 as the score with a percentage of $72,4 \%$.

Purchasing Decision overview on Gojek in Jakarta

From the descriptive analysis conducted about the response by respondents on the brand equity variable on Gojek, the result of the overall percentage is $72,8 \%$ (in good category). It means that Gojek has successfully influenced their customer to purchase with their excellence. As it can be seen from the highest score from the descriptive analysis of purchasing decision with the statement of "Gojek's features are easy to use", with 403 as the score with the percentage of $80,6 \%$.

The influence of storytelling marketing to brand equity on Gojek in Jakarta

Based on the hypothesis test conducted, the researcher was using SmartPLS, obtained a T-statistic value of 7,887, and the level of significance $>1,98$. Because this hypothesis test has fulfilled the requirement that $\mathrm{t}$-count is higher than $\mathrm{t}$-table 1,98 , so it can be concluded that storytelling marketing affecting brand equity. R square explained that affect the score of storytelling marketing to brand equity has the R square value of 0,313 or $31,3 \%$ and other $67,8 \%$ explained by the variable that not used in this study.

The influence of brand equity in purchasing decision on Gojek in Jakarta

Based on the hypothesis test conducted, the researcher was using SmartPLS, obtained a T-statistic value of 10,904, and the level of significance $>1,98$. Because this hypothesis test has fulfilled the requirement that t-count is higher than t-table 1,98 , so it can be concluded that brand equity affecting purchasing decisions.

The influence of storytelling markering to purchasing decision on Gojek in Jakarta 
Based on the hypothesis test conducted, the researcher was using SmartPLS, obtained a T-statistic value of 7,887 , and the level of significance $>1,98$. Because this hypothesis test has fulfilled the requirement that $\mathrm{t}$-count is higher than $\mathrm{t}$-table 1,98 , so it can be concluded that storytelling marketing affecting purchasing decisions. $\mathrm{R}$ square explained that affect the score of storytelling marketing to purchasing decision has the R square value of 0,646 or $64,6 \%$ and other $35,4 \%$ explained by the variable that not used in this study.

The influence of storytelling markering to purchasing decision through brand equity on Gojek in Jakarta

Based on the hypothesis test conducted, the researcher was using SmartPLS, obtained a T-statistic value of 7,225 with total indirect effect, and the level of significance $>1,98$. Because this hypothesis test has fulfilled the requirement that $\mathrm{t}$-count is higher than $\mathrm{t}$-table 1,98 , so it can be concluded that storytelling marketing affected purchasing decisions through brand equity as an intervening variable.

\section{ACKNOWLEDGEMENT}

1. My family always gave me strength and support.

2. Mrs. Farah Oktafani as my lecturer

3. Zulfaa Putri Nabiila who providing language help

\section{REFERENCES}

Aaker, A David. (1991). Managing Brand Equity, New York: Free Press.

Aaker, D. (2004). Managing Brand Equity Capitalizing On The Value Of Brand Name. New York: Free Press.

Alicia, Meika. (2014). Performance Analysis of Storytelling Marketing on Brand Equity in Carbonated Drink Product Coca Cola (Survey on Facebook Fan Page Community and Twitter Coca Cola Indonesia @CocaCola_id). Pendidikan Indonesia University.

Bryan, A. (2011). The New Digital Storytelling. USA: ABC-Clio.

Chiu, Hung-Chang, Yi-Ching Hsieh,Yi-Chu Kuo. (2012). How to Align your Brand Stories with Your Products. Journal of Retailing.

Dahlen, M., Lang F,. \& Smith, T. (2010). Marketing Communication: a Brand Narrative Approach. West Sussex: Jhon Willey \& Sond ltd.

Denning, Stephen. (2006). Effective Storytelling. Journal Strategy and Leadership. Vol 34 no. 1

Durianto, Darmadi (2013). Strategy To Win Market Through Equity Research and Brand Behavior (10th Edition). Jakarta: PT Gramedia Pustaka Utama

Frog, K., Budtz, C., Munch, P., \& Blanchetter, S. (2010). Storytelling Branding in Practice. Frderiksber: Samfunds Litteratur Press.

Hanggadhika, Herdian. (2010). Analysis The Effect Of Brand Equity On Purchasing Decisions On Nokia As Handphone Product In Semarang. Semarang.

Kotler, Philip and Kevin Lane Keller. (2016). Marketing Management. 15th Edition New Jersey: Pearson Pretice Hall, Inc.

Kotler, Philip and Kevin Lane Keller. (2012). Marketing Management. New Jersey: Pearson Pretice Hall, Inc

Kotler, Philip and Kevin Keller. (2009). Marketing Management (13th Edition). Jakarta: Erlangga.

Kotler, Plilip. (2000). Marketing Management. Jakarta : PT. Indeks Kelompok Gramedia 
International Journal of Management, Entrepreneurship, Social Science and Humanities (IJMESH), Vol. 3 (1), 48-55

The Effect of Storytelling Marketing on Purchasing Decisions Through Brand Equity as Intervening Variable on Gojek in Jakarta

Ridha Rizkia, Farah Oktafani

Pan, Lee-Yun. Kuan-Hung Chen. (2019). A Study on the Effect of Storytelling Marketing on Brand Image, Perceived Quality, and Purchase Intention in Ecotourism. Journal Business Administration. Ekoloji 28(107): 705-712(2019).

Peter dan Olson. (2013). Consumer Behavior and Marketing Strategy. Jakarta.

Pravitaswari, Nirakatrienna., Zainul Arifin dan M. Kholid Mawardi. (2018). The Effect Of Storytelling Marketing On Brand EEquity And Purchasing Decisions. Business Administration Journal.

Salzer-Mörling, M. and Strannegård, L. (2004). "Silence of the brands", European Journal of Marketing, Vol. 38 No. 1/2, pp. 224-238. https://doi.org/10.1108/03090560410511203

Suharyani, Komang. (2015). The Effect of Brand Equity On Purchasing Decisions The Botol Sosro In UNDIKSHA Student Majoring Economy Education.

Tjiptono, F. (2011). Managemnet \& Brand Strategy. Yogyakarta. 